\title{
Legal Synchronization Limitations of Children Under Age in Positive Legal Perspectives in Indonesia
}

\author{
Muklis \\ University of Muhammadiyah Sumatera Utara, Indonesia \\ muklis@umsu.ac.id
}

\begin{abstract}
The number of regulations regarding the age limit of a person said to be an adult in Indonesia actually creates legal uncertainty, because of the variety of these restrictions. Between the laws with one another it turns out to be mutually contradictory. Such a situation is certainly confusing for law enforcers such as judges to determine which laws will be chosen as the basis for deciding a case. One of the most interesting problems is the contradiction between Law No. 1 of 1974 concerning Marriage and Law No. 35 of 2014 concerning Amendments to Law No. 23 of 2002 concerning Child Protection. According to Law No. 1 of 1974, 16 years of age for women are able to get married, while in Law No. 35 of 2004, the age of 16 is still said to be a child. The existence of these contradictions shows that legal inconsistency has resulted in legal uncertainty.
\end{abstract}

Keywords : synchronization; restrictions; age; underage children

\section{Introdruction}

It turns out that a lower age limit for a woman to marry results in a higher birth rate than when compared to a higher age limit. With regard to that, Law No.1 Year 1974 stipulates the age limit for marriage for men is 19 years while for women aged 16 years. The age limit of children in the legislation in Indonesia is indeed very varied. All laws governing the age limit between children and adults are very diverse. When Law No. 35 of 2014 concerning Amendments to Law Number 23 of 2002 concerning Child Protection (here in after abbreviated as the Child Protection Act) is ratified, the child in Article 1 is someone who is not 18 (eighteen) years old, including child who is still in the womb.

The fact in Article 1 of the Child Protection Act is of course different from that found in Article 6 paragraph 2, 3, 4, and 5 which determines the age limit for marriage for 19-year-old men while for women aged 16 years. For men, of course it is not a problem, because the provisions contained in the Marriage Law and the Child Protection Act have no contradictions about the age limit, but not with women.

In Article 7 of the Marriage Law it is stated, to be able to get married, the male must have reached the age of 19 years and the woman has reached the age of 16 years. According to the perspective of the Protection Act, 16-year-olds in the minimum age of marriage for women have negative excesses, among the women of under 18 will lose their rights for example their right to acquire and access the level of education that is actually still entitled to belong.

The Marriage Act was established in that past, this arrangement about the age of marriage has in fact been in accordance with the principle of marriage stating that the future husband and wife should have unites the soul and the raga. The purpose of marriage is the purpose to create an eternal and well-happy family without ending in divorce and getting a good and healthy offspring to be realized. The opposite of underage marriage or often termed early marriage as prescribed by the Marriage Act should have been avoided for bringing less good effect, especially for the person carrying it. (Nuruddin and Tarigan, 2014: 72).

The reality gives birth to a minimum of two legal problems arising from underage marriage. First, the disharmonination of laws between legal systems is one with another legal 
system. Second, challenges to the legal legislation of marriage in Indonesia are related to underage marriage. Rahmita, www.repository.usu.ac.id.)

\section{Review of Literature}

\subsection{Age Limits of Children Under Age According to the Marriage Law}

Marriage has a very strategic role in community life. Marriage is the initial gate to form a family which is the smallest unit of a society. The family which is the smallest unit of society consists of husband and wife, or husband and wife and their children, or father with their child, or mother and child. The purpose of marriage is not limited to mere biological relations. Marriage has a further purpose than that, which includes loving life guidance so that people can live quietly in their families and communities.

To achieve the noble goal of marriage, of course, the bride and groom must cook their soul before marriage. This maturity is expected to realize the goal of marriage well without thinking about divorce and getting good and healthy off spring. (Rofiq, 2003: 57). On the other hand, there is a phenomenon of underage marriage that is quite interesting to the attention of various groups, this is because the phenomenon of underage marriage is like the phenomenon of an iceberg that looks a little above it even though in the plains the fact is very much happening among the people of Indonesia.

Provisions for the minimum age of marriage in Indonesia for the past 4 decades have not experienced progress and change. Why? This is because since the provision was established, namely in 1974, until now there is no increase in the standard against the minimum age for marriage. As is known, that in Article 7 paragraph (1) Law No. 1 of 1974 concerning Marriage is stated: "Marriage is only permitted if the male has reached the age of 19 (nineteen) years and the woman has reached the age of 16 (sixteen) years." This stagnation was compounded by the decision of the Constitutional Court (MK) on June 18, 2015 with No. 3074 / PUU-XII / 2014, which rejected the petitum of the applicants in the case of Testing Law No.1 of 1974 concerning Marriage to the Republic of Indonesia Constitution Indonesia in 1945. The Constitutional Court ruling emphasized that the minimum age requirement for marriage in this country was on the spot. The standard set for more than 40 years ago is still stagnant without changes. Whereas on the other hand, times have changed, socio-cultural, economic and people's lives in general are very different from the context of the 70s, the era in which Law No.1 of 1974 concerning Marriage was established. (Fuad, www.iainpontianak.ac.id).

Social change will influence and bring changes to the law, because when social change occurs, the needs of society will also change both quantitatively and qualitatively. It's just that the process of legal adjustment on social change usually takes place slowly, often the law must wait for the process of social change to reach a certain stage of crystallization and establishment to be able to emerge new legal principles, institutions and institutions. This fact gave rise to the expression: the law was teetering along with the events / events (het recht hinkt achter de feiten aan). (Sidharta, 2000: 26)

Maturity is always a measure of every action and responsibility carried out, so maturity is a very important factor in any social interaction, whether it causes legal consequences or is limited to the scope of public relations. (Witanto, www.hkmperadilan.blogspot.com). Responsible attitude is closely related to the level of maturity in the development of human life. In the perspective of law, the level of maturity is interpreted as a parameter that can state that someone is capable of law or able to do legal actions. (Alam, www.badilag.net) 
Discussing about maturity, cannot limit oneself to one or two scientific fields, but is forced to conduct interdisciplinary studies because maturity itself is used by almost all fields of social sciences, including among them: sociology, law, political science, economics even the science of religion is a matter of maturity and is a matter of principle and determination. When examined in its own legal field, maturity can determine the validity of a legal act. A person who is not yet mature is seen as a subject who has not been able to act alone before the law, so that legal action must be represented by his parents / representatives.

\subsection{Age limits for underage children according to Law Number 1 of 1974 concerning Marriage}

Many factors must be considered in order to realize a happy and eternal family, including the readiness and maturity of prospective husbands and wives to settle down. This readiness and progress includes physical, mental, and material. To realize this goal, one of the principles outlined in Law No. 1 of 1974 concerning Marriage is that a prospective husband and wife must have cooked their soul and body to be able to get married, so that they can realize their marriage goals without ending divorce and obtaining good and healthy offspring.

With regard to this principle, one of the standards used is the determination of the age of marriage. (Suma, 2005: 183). According to Law No. 1 of 1974 concerning Marriage Article 7 paragraph (1), the measure of maturity is implemented with the age limit that must be fulfilled as a condition for someone to marry. The age limit is 16 (sixteen) years for the prospective bride and 19 (nineteen) years for men. The age limit for prospective brides is clearly stipulated in Article 7 of the Marriage Law with the following formula:

Paragraph (1) Marriage is only permitted if the male reaches the age of 19 (nineteen) years and the woman has reached the age of 16 (sixteen) years.

Paragraph (2) In terms of irregularities in Paragraph (1) this article may request dispensation to the Court or other officials requested by both male or female parties' parents.

In Article 7 of the Marriage Act is mentioned, to be able to marry, the male party must have reached the age of 19 and the female side has reached the age of 16. Nevertheless, irregularities against such age limits may occur if there is a dispensation granted by the court or any other official appointed, by both parents on the part of the man and the female side. The rule in Article 7 triggers the number of marriages under age. Explicitly, it is not clearly listed for prohibition on marriage under age. Deviation of such rules can be possible in the presence of permission from a court or a competent official.

There was a dispute between religion (Islam) and the State in meaning of this underage marriage. Underage marriages undertaken did not pass the minimal limit of the Marriage Act, legally statehood is invalid. The term underage marriage by State is limited by age. According to the religious perspective, marriage under age is a marriage committed by an unbalighed person. The reality created to a minimum of 2 (two) legal issues arising from underage marriages. First, disharmonize the law between legal systems that are one with another legal system. Second, challenges to the legal legislation of marriage in Indonesia are related to underage marriage. (Panjaitan, www.repository.usu.ac.id) 
Article 47 of the Number 1 Act of 1974 on Marriage:

Paraghraph (1) Child who has not reached age 18 (eighteen) years or has never undertaken marriage is under the rule of her parents as long as they are not revoked of her powers.

Paraghraph (2) Parents represent the child as to all legal deeds in and out of court.

It turned out that the Marriage Law saw the terms of the marriage concerned only the consent of both candidates and the limitations of age as well as the absence of a marriage impediment between the two bridegroom candidates. These two are decisive for the achievement of the purpose of marriage itself. The consent of the two candidates disbelieved the marriage was not underlain by coercion. This terms at least hint at the presence of female emancipation so that each woman can freely determine her choice of who is best suited and mashlahat (goodness) as her husband. So here there's no compulsion, what's more on the community that's advanced. (Rasjidi, 1982: 111). Under the provisions in those articles are closely observed, it can be understood that the Marriage Law does not expressly define the adult age limit, even some of those provisions in passing appear to be mutually opposite.

A male who is 19 years old and a female who is 16 can do the act of mating. Mating is a legal deed that is consequently broad in law, among others changing status, obliging to make a living and leading a household for men, taking care of households and educating children for women and others. The lawful person doing the mating law act means having grown up, when for a female she is only 16 years old. On the other hand, if the bride is not 21 years old, to be able to perform a mating must have permission from her parents or guardians. (Astrophy, www.badilag.net). It is cursory to look a ration. The Marriage Law allows mating/marriage but to do the deeds allowed by the law, the Marriage Law requires the permission of the elderly if the age is not even 21 .

\subsection{Limit the age of minors according to Law No. 35 of 2014 concerning Amendments to Law No. 23 of 2002 concerning Child Protection}

Children are the mandate as well as the gift of God, which must always be maintained because in him the inherent dignity, dignity and rights as human beings must be upheld. Child rights are part of human rights contained in the 1945 Constitution and the United Nations Convention on the Rights of the Child. From the side of nation-life and country, children are the future of the nation and the next generation of nation ideals, so that each child is entitled to survival, growing and developing, participating, as well as being entitled to protection from acts of violence and discrimination and civil rights and freedom. (Koro, 2012: 63)

The age limit provides grouping against a person to be referred to as a child. Child age limits are maximum age groupings as a form of child ability in legal status, so that child switches status to adulthood or becomes a legal subject who can be independently accountable for the deeds and legal actions that the child performs. To establish a more prospective legal provision in laying the maximum age limit of a child, a highly diverse opinion of the legal standing is given to the status of maturity of a child.

Law No. 39 of 1999 concerning Human Rights has included the rights of children, the implementation of the obligations and responsibilities of parents, families, communities, government, and the state to provide protection for children still requires a law on child protection as a legal basis for the implementation of these obligations and responsibilities. 
Thus, the establishment of a law is felt necessary with consideration that child protection in all aspects is part of national development activities, particularly in advancing nation-life and state-runs let alone associated with welfare states.

Law No.23 of 2002 Article 1 paragraph (1) which was later amended by Law No.35 of 2014 concerning Amendment to Law No. 23 of 2002 concerning Child Protection states that what is meant by a child is someone who is not yet 18 (eighteen ) years, including children who are still in the womb.

Parents, families, and communities are responsible for keeping and maintaining such rights in accordance with the obligations charged by law. Similarly in order to organize child, state and government protection is responsible for providing facilities and accessivity for the child, especially in guaranteeing its optimal and purposeful growth and development directed towards the development of human resources quality. Legal protection for children asserts that the liability of parents, families, communities, governments and states is a continuous series of activities implemented in favor of the protection of child rights. The set of such activities should be sustainable and purposeful in order to ensure child growth and development, both physical, mental, spritual, and social. This act is intended to bring about the best life for the expected child as a potential, formidable successor to the nation, having nationalism imbued by noble morals and Pancasila values, as well as strong will to maintain unity and unity of the nation and the state. (Koro, 2012: 63)

Child protection efforts need to be carried out as early as possible, from the fetus in the womb to the age of 18, which is the starting point of the conception of child protection that is intact, comprehensive and comprehensive. Efforts to protect children are inseparable from forms of protection. Article 2 of Law No.4 of 1979 formulates the rights of children as follows:

1. Children are entitled to welfare, care, care and guidance based on love both in his family and in special care to grow and develop naturally

2. Children are entitled to service to develop their abilities and social life, in accordance with the personality of the nation and to become good and useful citizens

3. Children are entitled to the maintenance and protection of both the time in content and after birth

4. Children are entitled to protection against living environments that can harm or inhibit growth and development reasonably.

Child protection is based on Pancasila and the 1945 Constitution and the principles of the Convention on the Rights of the Child, which include:

1. Non Discrimination

2. The best interests of the child

3. The right to life, survival and development

4. Appreciation of children's opinions (Article 2 of Law No. 23 of 2002) (Waluyadi, 2009:14)

The basic understanding of life, survival and development is that basic human rights for children must be protected by the state, government, society, family and parents. That is, these parties, must realize and not negate the rights in question (the right to life, the right to survival and the right to develop). The definition of the principle of appreciation for children's opinions is the respect for the right to make decisions, especially on matters relating to their lives. 


\section{Discussion}

The explanation of the Marriage Law is asserted in more detail that as a State based on Pancasila, where the first precept is the One Godhead, so marriage has a close relationship with religion/cravacy, so marriage has not only an element of birth/corporation, but the inner element/rohani also has a very important role. Forming a family that addresses relationship meetings with offspring, which is the purpose of marriage, maintenance and education into parental rights and obligations. (Sudarsono, 1991: 9).

Underage marriage is a marriage that occurs in which the unreached party of a man or woman is already conditioned in the applicable law, that is, when the male party reaches 19 years old. Mating of a man who is already akil baligh (adult) with an immature woman can be at legitimate value

Determination of the age limit to brewing is of particular importance, as a marriage wills biological maturity is also psychological. The General Explanation of Law No.1 of 1974 About Marriage was stated, that the prospective husbands must have cooked their souls to be able to carry on the marriage in order to be able to manifest the marriage well without ending up in divorce and get good and healthy offspring. For this reason, it is necessary to prevent the existence of a young marriage to prevent the practice of marriage being "too young", as happens in many villages, which has a variety of negative consequences. Article 7 paragraph (1) The Marriage Law stipulates that men must have reached the age of 19 years and women must have reached the age of 16 years, only to be permitted to carry out marriage.

The article and its explanation, do not mention what can be used as a basis for an important reason for the needs that are urgent for the family's interests, then dispensation can be given, because with no mention of an important reason, it is easy for everyone to get the dispensation.

In addition to the age restrictions mentioned above, Article 6 paragraph (2) includes provisions that require every person (male and female) who has not reached the age of 21 (twenty one) years, to get permission from both parents. If the permission is not obtained from the parents, the Court can give the permit based on the request of the person who will carry out the marriage. (Sudarsono, 1991: 65). The act of permission from parents for children who will carry out marriage where the child is not yet 21 years old is the implementation of the principle of family participation as adopted in Law No. 1 of 1974 concerning Marriage. Marriage is an important event in someone's life, because he will enter a new world, forming a family as the smallest unit of the Indonesian family that is religious and family, so family participation is needed to bless the marriage. For those under the age of 21 for men and women, permission from parents is required. (Mardani, 2011: 21)

According to the provisions of article 1 paragraph (2) of Law No.4 of 1961 concerning Changes or Additions to Family Names, the adult definition referred to in this law is that it is even 21 years old or has or has been married. Provisions for adulthood are not always the same so that in this regulation there is a self-determination regarding the status. The provisions of maturity stipulated in article 1 paragraph (2) of Law No. 4 of 1962 do not have meaning for those who submit to the European Civil Law because the age of maturity is regulated in the provisions of article 330 of the Civil Code (Civil Code). Conversely, the maturity limit will follow the legal provisions that apply to other Indonesian citizens who are not subject to the Civil Code, even though the limit is not necessarily the same. 
The importance of maturity to be used as a measure for someone to be declared capable of law needs to be studied in depth because real maturity is an important factor to perpetuate relationships in marriage. For this reason, it is necessary to formulate ideal marriage age provisions supported by other than scientific evidence, as well as logical arguments so that in turn it can function as an indicator of maturity. (Nature, www.badilag.net)

The determination of maturity invariably occurred due to the difference in legal viewpoints to societal problema in all social levels. According to the Law No.23 of 2002 on Child Protection as amended with the Law No.35 of 2014 on the Amendment Under Law No.23 of 2002, the category of children is a person still under the age of 18, whereas in the Law No. 26 of 2000 on the Court of Human Rights formulated an 18-year-old adult category, the Law No.30 of 2004 on Notary Barriers, declared adult terms 18-year-old (or already married).

The provisions of the age of maturity that differ from each other indicate that understanding and agreement on the age limit of maturity does not yet exist in Indonesia. Given the issue of marriage is a sacred problem, closely related to the formation of society, closely related to the attachment of responsibility accompanied by the emergence of rights and obligations, then it is appropriate for a man's age to marry and increase more than 19 years for men and 16 years for women.

According to Andi Sjamsu Alam, marriage is only worth the adult human being, in the adult human sense it can account for his deeds. Each mature married couple has a more mature level of psychological development compared to a spouse executing a marriage before adulthood. Consequently, marriages performed by couples who have not reached adult tarafs, are difficult to think and act responsibly. (Nature, www.badilag.net)

As an adult human act, marriage is an event that can take place after consideration both rationally and emotionally or mentally. In addition to thinking and being accepted by common sense, all marriage preparation is the mental preparation of the prospective partner itself. This mental preparation starts from the simplest thing, which is to know and understand your partner and understand the meaning of marriage. In the stage of marriage preparation, fostering romantic and harmonious social relations is important and needs to be undertaken. (Nature, www.badilag.net)

Marriage is a legal event and as a legal event, the legal subject who carries out the event must meet the requirements. One of the requirements of humans as legal subjects to be able to be said to be capable of carrying out legal actions is to be mature. Considering the law governing marriage is Law No. 1 of 1974 concerning Marriage, the provisions in the Marriage Law must be adhered to by all groups of people in Indonesia.

One of the principles espoused in the Marriage Act was that prospective husbands should have matured in terms of their psychiatric and raga to be able to carry out marriage. It means nothing but being able to bring about marriages well without ending up in divorce and acquiring good and healthy offspring. For that it should prevent marriage between the potential husbands of the underage.

According to the perspective of psychology science, an individual is declared adult if it has been loose or past adolescence. As for adolescence is the age stage that comes after childhood ends and is characterized by rapid physical growth. The rapid growth that occurs in the outside and inner adolescent body, brings about not a slight effect on her attitude, behavior, health as well as personality. (Daradjat, 1995: 8). This cases brings education and psychology experts inclined to name those stages of the switch in a group of its own, namely the adolescents that are the intermediate stages of childhood, as well as preparations for entering adulthood. 
Furthermore, Kartono said that adolescence is also a period of contact or transition between childhood and adulthood. The adolescent period has major and essential changes regarding spiritual and physical functions. Very prominent in this period was a deep awareness of oneself where adolescents began to believe in their abilities, potential and ideals themselves. With this awareness teenagers try to find their way of life and start looking for certain values, such as goodness, nobility, wisdom, and beauty. (Kartini \& Kartono, 2005: 33)

Marriage as an institution, viewed from a sociological perspective is a family institution that not only guarantees human survival, but also guarantees dignified social stability and existence for men and women in its society. Marriage institutions built by couples that have psychologically not yet had maturity, can cause disharmony in society, as can be seen in the phenomenon of displaced children. (Nature, www.badilag.net)

In the development of the passage of the Law No. 1 of 1974, particularly related to Article 7 verse (1), the divorce rate is relatively high caused by health factors. One of the health problems that led to the divorce was related to the reproductive health of women that in turn resulted in couples being unable to have offspring. When article 7 of Paraghraph 1) of the Marriage Act determines the age of a woman's marriage at 16, then the warning of health experts is worth the ingredient of consideration to reflect on the risks that will occur for women. Some health experts state that marriages from young age couples for women, especially under 17 years of age are at risk of cervical cancer.

A person who has grown up is considered capable of doing because he has juridical power at his will so that he can also determine the legal situation for himself. The law states that adults who have been able to calculate the extent of the consequences of expressing their will in a legal action, such as making an agreement, making a will. The age of 21 is a significant ideal age in building or creating an ideal marriage. Although the age of 21 years was not explicitly mentioned, but in a more practical statement, according to Shihab, it was shown that the ideal marriage was built from a mature or mature couple. (Shihab, 2000: 212)

The issue of marriage age difference between men and women, which is 16 years for women and 19 years for men in Article 7 paragraph (1) Marriage Law , departs from the assumption that the husband should always be more mature and more capable of his wife. This is due to because the husband is positioned as head of family and breadwinner, whereas the woman is placed as a subordinative party. Equality in terms of ideal age, it is more assertively meaningful that the age of men, that is, 21 years is the same as the age of women. Each of the married couples was at the age of 21 with the consideration that psychological, sociological, and health aspects, were both balanced.

The balance of the ideal age of mating between men and women that is 21 years of age provides legal certainty and legal protection for the child and his rights. Congratulations case, 16-year-old male adolescent married to 17-year-old Rohaya grandmother as well as marriage between 43-year-old Sheikh Pujiono Cahyo Widianto and then 12-year-old Lutfia Ulfa, although religiously (Islam) declared legal, but the rights of both of whom are still counted children in legal context in Indonesia, make both of her rights as children who have been protected by the State.

According to Frans Magnis Suseno, the property of law, in addition to guaranteeing legal certainty in its implementation, also sought the upright of justice. And justice has two meanings, and it is formil of justice to demand that the law be common. In a material sense it is prosecuted to have the law conform to the ideals of justice in society. (Suseno, 1988: 81). The justice in question is justice in a material sense; the content of the law must be fair. The 
intent to realize a fair common life order includes the nature of the law itself. A law that doesn't want to be fair is not a law. The necessary and recognized things of society are not just any normative order, but rather an order that supports a common life, based on good and reasonable judgment. Under the argumentation, the direction of the implementation of justice is constitutive, or is a prerequisite of property for the law.

\section{Conclussion}

That the legal certainty of underage child marriages becomes blurred due to the existence of mating dispensation granted by the Law No.1 of Year1974 and Compilation of Islamic Law, so law enforcement of underage children does not obtain legal validity, leading to child rights being neglected. On the other hand, the amount of regulation pertaining to the adult age limits of a person becomes an obstacle to the realization of enforcement of child rights. Based on that fact and reality, it is necessary for a shared faculty to re-formulate the age limit of a person to become an adult. That overlapping regulation renders the law no longer in accordance with its purpose that is expediency, certainty and justice.

\section{References}

Abdi Koro, 2012, Perlindungan Anak Dibawah Umur. Bandung: PT. Alumni,

Ahmad Masfuful Fuad, "Menelaah Kembali Ketentuan Usia Minimal Kawin Di Indonesia Melalui Perspektif Hermeneutika", melalui www.iainpontianak.ac.id, accessed July 5, 2017.

Ahmad Rofiq, 2003, Hukum Islam Di Indonesia, Jakarta: PT RajaGrafindo Persada,.

Ahmad Sofian dan Misran Lubis, tentang "Tulisan Dalam Diskursus dan Penelitian Tim Pusat Kajian dan perlindungan Anak (PKPA)", melalui www.kompas.com, accessed July 17, 2017.

Akhmad Shodikin, "Pandangan Hukum Islam Dan Hukum Nasional Tentang Batas Usia Perkawinan", dalam Jurnal Mahkamah, Vol. 9 No. 1 Januari-Juni 2015.

Amiur Nuruddin dan Azhari Akmal Tarigan. 2014. Hukum Perdata Islam di IndonesiaStudi Kritis Perkembangan Hukum Islam dari Fikih, UU No.1/1974 sampai KHI. Cet. Ke-5.

Andi Sjamsu Alam, "Usia Perkawinan Dalam Perspektif Hukum Dan Kontribusinya Bagi Pengembangan Hukum Perkawinan Indonesia, melalui www.badilag.net, accessed July 19, 2017.

Antonius Wiwan Koban, "Revisi Undang-Undang Perkawinan" dalam Adinda Tenriangke Muchtar (ed.), Update Indonesia, The Indonesian Institute, Vol. IV No. 10, Maret 2010.

Arief Sidharta, B, 2000, Refleksi tentang Struktur Ilmu Hukum: Sebuah Penelitian tentang Fundasi Kefilsafatan dan Sifat Keilmuan Ilmu Hukum sebagai Landasan Pengembangan ilmu Hukum Nasional Indonesia, $2^{\text {nd }}$ print, Bandung: Mandar Maju.

Asrofi, "Batas Usia Dalam Perspektif Hukum Dan Penerapannya Pada Pengadilan Agama", melalui www.badilag.net, accessed Juli 14, 2017.

Edwin Hadiyan, "Membangun Kesadaran Masyarakat Mengenai Tradisi Pernikahan Dibawah Umur Terhadap Hak Anak" dalam Jurnal Studi Gender dan Anak, Vol. 3 No. 1 JanuariJuni 2016.

Farida Ariany, "Perkawinan Usia Dini Menurut Hukum Islam Dan Undang-Undang Nomor 1 Tahun 1974 Tentang Perkawinan", dalam Jurnal Sangkareang Mataram, Vol. 3 No. 1 Maret 2017. 
Franz Magnis Suseno, 1988, Etika Politik, Jakarta: Gramedia.

Irma Setyowati Soemitro. 1990. Aspek Hukum Perlindungan Anak. Jakarta: Bumi Aksara.

Kartono, Kartini, 2005, Psikologi Anak. Bandung : Bandar Maju.

Lili Rasjidi, 1982, Hukum Perkawinan dan Perceraian di Malaysia dan Indonesia, Bandung: Alumni.

Mardani, 2011, Hukum Perkawinan Islam di Dunia Islam Modern, Yogyakarta: Graha Ilmu.

Muhammad Amin Suma, 2005, Hukum Keluarga Islam di Dunia Islam, Jakarta: Rajawali Press.

Muhammad Isna Wahyudi, 2014, Pembaharuan Hukum Perdata Islam Pendekatan dan Penerapan, Bandung: CV Mandar Maju.

Panjaitan, Linda Rahmita, "Perkawinan Anak Dibawah Umur Dan Akibat Hukumnya", melalui www.repository.usu.ac.id., accessed July 10, 2017.

Quraish Shihab, M., 2000, Membumikan al-Quran: Fungsi dan Peran Wahyu dalam Kehidupan Masyarakat, Bandung: Mizan.

Soemiyati, 2007, Hukum Perkawinan Islam dan Undang-Undang Perkawinan, Yogyakarta: Liberty.

Sudarsono, 1991, Hukum Perkawinan Nasional, Jakarta: Rineka Cipta.

Sudikno Mertokusumo, 1988, Penemuan Hukum (Suatu Pengantar), Yogyakarta: Liberty.

Waluyadi. 2009. Hukum Perlindungan Anak. Bandung: Mandar Maju.

Wila Chandrawila Supriadi, 2001, Perempuan dan Kekerasan dalam Perkawinan, Bandung: Mandar Maju.

Witanto, D.Y, "Pluralisme Batas Kedewasaan Dalam Sistem Hukum di Indonesia (Kajian Sudut Pandang Interdisipliner), melalui www.hkmperadilan.blogspot.com, July 182017.

Zakiyah Daradjat, 1995, Remaja Harapan dan Tantangan, Bandung: PT Remaja Rosdakarya. 